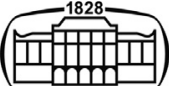

AKADÉMIAI KIADÓ

International Review of Applied Sciences and Engineering

$11(2020) 2,157-166$

DOI:

$10.1556 / 1848.2020 .20026$

(C) 2020 The Authors

\section{ORIGINAL RESEARCH}

PAPER

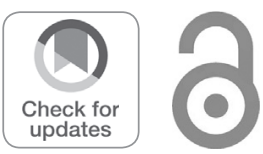

\title{
The role of rural areas in the preservation of health
}

\section{NORBERT NOVÁK ${ }^{1 *} \odot$, PÉTER MIKLÓS KŐMÍVES 2 , MÓNIKA HARANGI-RÁKOS ${ }^{3}$ and KÁROLY PETŐ ${ }^{4}$}

\author{
${ }^{1}$ Károly Ihrig Doctoral School of Management and Business, University of Debrecen, Faculty of \\ Economics and Business, Institute of Rural Development, Regional Economy and Tourism \\ Management, Debrecen, Hungary \\ ${ }^{2}$ Károly Ihrig Doctoral School of Management and Business, University of Debrecen, Faculty of \\ Economics and Business, Institute of Management and Organization Sciences, Debrecen, Hungary \\ ${ }^{3}$ University of Debrecen, Faculty of Economics and Business, Institute of Regional Economy and \\ Tourism Management, Debrecen, Hungary \\ ${ }^{4}$ University of Debrecen, Faculty of Economics and Business, Institute of Rural Development, \\ Regional Economy and Tourism Management, Debrecen, Hungary
}

Received: August 09, 2019 • Accepted: September 23, 2019

Published online: June 30, 2020

\begin{abstract}
The role of rural areas partly changed in the last decades. The countryside is still functioning as the main food producer of the world and this role became much more important because of the global population growth and because of the change in dietary habits. But other rural functions appeared just like recreation, health preservation, and on the other hand the different ecological functions' importance increased. The population living in the countryside is continuously decreasing as more and more people try to move into urban areas. One of the main aims of this article is to give a brief literature overview on the services needed in the rural areas in order to stop migration from the countryside to the cities. Based on extensive literature review the article summarizes the changing functions of the countryside and tries to list those developments which are needed to preserve rural population.
\end{abstract}

\section{KEYWORDS}

countryside, services, migration, rural development, rural-urban differences

\section{INTRODUCTION}

People living in urban or rural areas face different but in many cases similar opportunities and challenges. Urban areas are characterized by a high density of people, consumers, employees and businesses. However, high population density in cities might lead to migration, increased pollution and waste, and the exacerbation of transportation-related social and employment challenges and tensions amongst different urban populations.

Currently, rural areas experience major structural changes. These changes include the shifts in different gender roles in the countryside causing changes in the different duties completed by women and men [1], the migration of the population from rural to urban areas not only in developed countries but in such developing economies like China [2] or in Hungary in the case of the young population studying in urban higher educational institutions [3], the decrease and the changes of the rural youth's desired occupation causing employment problems in the agricultural sector of the developed countries like Germany [4]. On the other hand, the rural ecology is also facing several challenges caused by the changing nature of the agricultural production and the changing functions of the countryside including the negative impact of the monoculture agriculture with special regards to the genetically engineered crops [5], the limited attention payed to the negative impacts of 
the agroecological theory in the agricultural practice [6], and the late efforts done in order to strengthen the shift to the sustainable agricultural production including the reduction of greenhouse gas emission, the reduction of the loss in the biodiversity and causing less harm for human health [7].

Globalization, the emergence of new sectors and the decline of traditional agricultural dominance are creating new opportunities and challenges. Similarly to the changing tendencies of urban and rural environments, preferences of people are also very diverse and they might change over the course of their lives. The difference between a big city and a small town allows for a different lifestyle. They possess basically similar infrastructural opportunities (both of them are cities), but larger cities are very different from a small town in terms of quantity and quality. The benefits of small towns might be for example a calmer and healthier lifestyle, but this may not be necessarily true in every respect.

The present study demonstrates the role of rural areas in health awareness. We decided to investigate the connections of the rural lifestyle, the sustainability, and the sustainable development with special regards to food production. As a part of our research we also analysed the actual characteristics of the rural areas located in the EU-28. The final part of this article investigates the connections of the rural areas and the health promotion. The countryside is usually considered to be a place where people can find possibilities to strengthen their health.

\section{MATERIALS AND METHODS}

The study is based on publications which deal with the importance of the role of the countryside in the economic and social aspects of the research area. For the analysis, international research, reports, technical books and scientific publications that are closely related to the research area were utilized. In the course of the analyses, the role of rural areas in health awareness was examined in order to highlight the importance of rural areas and their contribution to a healthy life. There is a growing number of technical literature dealing with the role of the countryside in health preservation.

For the collection of statistical data and reports the online databases of HCSO, EUROSTAT, FAO, OECD were used. Collection of articles and studies was carried out using the search databases of GOOGLE SCHOLAR, GOOGLE. COM, ECONBIZ.DE, MATARKA, SCOPUS. The findings of our study may be prejudiced because it focuses on and summarizes the potential or actually realized effects and outcomes.

\subsection{Correlation between population growth and urbanization}

A strong correlation can be observed between population growth and urbanization. As the population grows, the proportion of urban population is constantly increasing, contributing to the depopulation of rural areas. Changes in global population also have a direct impact on the natural environment. Undoubtedly, population growth is one of the main drivers of global changes. In our time, more and more researchers deal with studies presenting the changes in global population and the resulting situation. Some previous analyses need to be highlighted, for example the predictions of refs. [8-16] based on previous census data that forecasted global population growth based on national data, as well as the studies of EASAC, FAO and OECD [17-19] based on constantly updated data.

Over the past nearly 10,000 years, the pace of growth has been fluctuating. However, as a result of the industrial revolution and the realized advances in health and medicine parallel to it huge differences were made. By the end of the 1800 s, the global population had reached or exceeded one billion (today, however, China alone has a population of 1.4 billion) [20]. In just 30 years following the industrial revolution, global population has doubled to more than 3 billion (1960). Thus, it can be stated that in the 20th century, global population increased from 1.65 billion to 6 billion. In 1970, only about half as many people lived in the world as today [21]. Following the previous extremely rapid population growth, the annual rate of population growth has declined over the past few decades. Population growth peaked in 1962 $(2.1 \%)$ and has since fallen to almost half [22]. Currently, the growth rate has dropped to $1.2 \%$, which is slightly less than 80 million people annually. According to predictions, annual growth rates are expected to fall to $0.1 \%$ by 2100 [23].

If current global trends continue and population growth tendencies remain unchanged, an additional 2.4 billion people will live in developing countries by 2050 (South Asia and sub-Saharan Africa are expected to face continuous growth in population). Size of urbanized areas is expected to increase threefold between 2000 and 2030 [24]. In these urbanized regions, agriculture is of major importance in terms of the national economy. $75 \%$ of the people with the lowest income in the world live in rural areas, where agriculture is their primary source of income [25]. Despite the above, approximately more than $20 \%$ of that population has food security problems [26]. Urbanization keeps taking more and more land away from agricultural areas and keeps putting pressure on current land use and biodiversity [27] while the humankind is using more natural resources than nature is able to produce again [28]. Urbanization is accompanied by a transformation of lifestyle and consumption habits. Combined with income growth, urbanization accelerates the diversification of diets in developing countries. While the consumption of cereals and other crops will decrease, the consumption of vegetables, fruits, meat, dairy products and fish will increase. Increasing demand for semi-processed or ready-to-eat foods will lead to further concentration of the food chain. While the proportion of urban populations will rise, rural areas continue to be the home of the majority of poor people, where even hunger is not a rare phenomenon. At present, 0.8 billion people are unable to meet their essential needs of food and energy [29, 30]. 
Rapid changes in eating habits are also connected to urbanization. People who quit farming activities move to cities in large numbers, where their eating habits also change. Currently, more than half of the global population is already urban, and in the future, their proportion will inevitably continue to grow. As a result of urbanization and international trade liberalization, the distance between the geographical centres of production and consumption keeps increasing, which results in an increase of the significance of transportation, storage and refrigeration, as well as the cost of the management of goods [31]. The connection between the food and fuel prices is still an important research question and they have been tightened in the last decade [32].

\subsection{Sustainability and food production}

One of the greatest challenges of the 21st century is to change the human lifestyles in a sustainable way. Traditionally those values which are related to sustainability could be found in the countryside where people can live their life in harmony with nature - or at least they have the possibility. The concept of environmental limits always has to be kept in mind [33]. In the Western world two different targets are assigned: the well-being as a current quality of life and the sustainability as the long-term prerequisite of this aim [34]. The sustainable development as a theory or as a discourse has been created as a fusion of different social development and ecological theories aimed to find the relationship and the balance of the economic development and the environment or the society and the environment [35]. During creation of different plans and systems we always have to pay attention to the latest new and novel tools and processes of sustainability in regulations as well. In many cases the sustainability has conflict with the development plans [36]. The growth-based development theories are counting with sustainability in the last - at least - three decades but they did not reach a break-through during their existence. That means nowadays sustainability does not play that important rule in the group of factors affecting the ways of economic development as it should play [37].

We can draw differences between sustainability and sustainable development. In a wider sense sustainability is the environmental aspect of the sustainable development [38]. In a narrower sense the sustainability is only interpretable in the case of processes while the sustainable development theory concerns different products - so it is the upshot of the sustainability process [39]. Sustainability can be investigated on international, national, regional, local and organisational levels as well and it can be investigated in social, economic and environmental ways too [40]. An economy can be evaluated sustainable if it can produce enough quantity of food with high quality and protect the natural resources while it is not hazardous for the environment and it is able to make profit as well. A sustainable farm prefers to use additives produced by itself and not bought on the market. In some cases, for example in the case of fertilizers it is not that easy [41]. The sustainable management of the ecosystem means we can realise, understand and adapt a part of the ecosystem services according to the needs of the ecosystem in order to support the functioning of the ecosystem by realising reforms needed on different levels [42].

The global economic analyses mainly concentrate on economic growth where the positive economic growth is a desirable aim and zero growth or negative growth should be avoided. But, unfortunately, the positive economic growth has effects on the environment - we can say that ultimately economic growth is harmful for the environment. On the other hand, negative economic growth causes the increase of unemployment rate globally and locally as well so the reduction of the economic growth cannot be the solution of this phenomenon. The third solution is a kind of "mean" between the two radical ways: the restructuration of economic measurement in a way that pays more attention during the calculation of economic growth to those factors which are working in a more environmental friendly way [43]. But until the global counting of different economic indicators will not be reformed the economists and the decision makers will always concentrate on those measurement factors which are affecting the main economic indicators. That means researchers, specialists and decision makers have to find the way of how sustainability could be more supported with regards to the economic growth.

Honestly the notion "well-being" has different meanings mainly influenced by the milieu where we use it [44]. It will have different meaning in a peaceful place and in a region suffering from violence. It will have different meaning in a developed area, in an emerging region and in lagging areas as well. The well-being aims always have to be defined based on the actual situation of the region where we would like to apply it and based on the people who are aimed to get involved in activities related to the well-being. A research conducted on a sample of people living in the rural Ecuador showed that the well-being not only depends on the personal income or employment status but on those circumstances as well which are listed as parts of the indigenous Buen Vivir well-being - theory including community relations, environmental friendly living habits and sovereignty in food production [45].

The countryside is rapidly changing. However, the original functions the countryside used to fulfil are still existing and working but many new functions appeared. Nowadays the countryside is not only used for agricultural production but for recreation and leisure activities as well. The countryside functions as a place for amenity and living [46]. The rural development possibilities are mainly dependant on the internal sources of each rural area. The ways how the areas could be developed depend on the locally available human capital, economic capital, social capital, nature capital, and physical capital affecting the local population's development level [47].

Gliessman $[48,49]$ defined the criteria of the sustainable agriculture with special regards to the different levels of the 
socio-ecologically sustainable food system. In the first stage we have to increase the efficiency of the food production system in order to decrease the raw material consumption. In the second stage we have to change the raw materials and processes used for more sustainable options. In the third agroecological stage we have to redesign the structures and system used with respect to ecological principles. Finally, in the fourth stage where we can pay attention to the social aspects of the agroecology we have to create the connection between producers and consumers again in order to support the socio-ecological reforms of the food systems.

Independence or sovereignty of food production is one of the possible ways of how sustainability can be reached and how sustainability can serve the needs of the healthy nutrition goals. In the countryside if enthusiastic people are starting to cooperate in order to produce healthy food the first - and most important step - is already done on the way to sustainable nutrition. But on the other hand, people starting to produce healthy foods for themselves will also need appropriate tools, time, commitment, knowledge and skills to reach their goals [44].

\subsection{Characteristics of rural areas of EU-28}

There are significant differences in the relative size of the rural population in the case of EU Member States. In 2015, only a quarter $(28.0 \%)$ of the EU-28 population lived in rural areas, with a slightly higher proportion living in suburbs (31.6\%), while the majority of the EU-28 population lived in urban areas (40.4\%) [50]. During the five-year period from 2010 to 2015, the number of people living in rural areas increased gradually. In the EU-28, the relative share of the rural population within the total population increased by 1.7 percentage point; the rise of the proportion of people living in suburban areas was even higher (by 4.7 percentage points), while the proportion of people living in urban areas declined at a relatively rapid rate. In Lithuania, Luxembourg, Slovenia, Latvia and Hungary, a relatively large proportion of the population lives in rural areas. In contrast, a relatively low percentage of the total population lives in rural areas in Germany (22.4\%), Italy (18.9\%), Belgium (18.0\%), and the United Kingdom (14.9\%) [50].

The risk of poverty or social exclusion was highest in rural areas of the eastern and southern EU Member States [51]. This is particularly true in Bulgaria, Romania and Malta, where at least half of the rural population was threatened by poverty or social exclusion in 2015. In Romania (and Malta), people living in rural areas were twice as likely to face the risk of poverty or social exclusion as those living in urban areas. In contrast, rural populations in Austria, the Netherlands, Belgium, Denmark, Germany and the United Kingdom are much less at risk of poverty or social exclusion than those living in urban areas [50]. It is interesting to point out that the analysis by Member State showed a significant geographical division: on the one hand, in the eastern, southern and Baltic Member States, the greatest risk of poverty or social exclusion was generally found among the rural population; in contrast, in most western and northern Member States, the greatest risk of poverty or social exclusion is generally observed in the case of the urban populations [52].

\subsection{Differences in the living standards of rural and urban life}

Population density has a significant impact on the socioeconomic characteristics and sustainability of urban and rural communities. However, it is important to underline that both urban and rural areas are essential for the wellbeing and quality of life of Europeans. Cities are the centres of economic and social development and innovation and therefore attract a large number of people through a wide range of educational, employment, entertainment and cultural possibilities. However, the high concentration of people and wealth often entails numerous complex economic, environmental and social challenges [53]. Romão et al. [54] have shown that the attractiveness of cities is influenced by the social dimension of sustainability, while the appearance of the urban environment also has a significant influence on the reputation of settlements from the point of view of attractiveness.

The difference between a large city and a small town allows for a different lifestyle. They have basically similar infrastructural opportunities (both are cities), but large cities are very different from small towns in quantitative terms, and this quantitative difference often entails qualitative differences $[55,56]$. A smaller population does not necessarily mean a disadvantage; with proper municipal development and the resources available for this purpose, development success can be achieved even in less developed regions at the level of individual settlements. However, if a small town is located near a larger settlement, it typically has a beneficial effect on the attractiveness of such towns, the opportunities available there, including job opportunities as well as various forms of entertainment [57]. Still, the proximity of larger settlements can also be dangerous to the operation of smaller settlements, which can thus become commuter towns. They are characterized by a large number of commuting people who live in the town but increase the economic performance of other settlements through their work.

As a result, existing disparities between cities and small settlements existing on their periphery may be further exacerbated [58]. Available work, which is the most important basis for the financial well-being of the population, is of utmost importance for the sustainability of rural areas. Accordingly, settlements where job opportunities suited to the local educational structure are available to the population can be successful [59]. While a wider range of products is easily available in cities, opportunities are more limited in rural areas. People living in the countryside regularly go to shopping malls on the outskirts of large cities for products that people living under urban circumstances are able to easily obtain. Therefore, the difference between 
urban and rural lifestyles also leads to differences in consumption habits [60].

Currently, the differences between urban and rural lifestyles are diminishing. On the one hand, rural people are also increasingly able to enjoy the same leisure time activities as urban people, on the other hand, more and more urban people spend their leisure time outside cities. However, it is important to note, that even in countries where the majority of the population lives in rural areas, resources are concentrated in cities [27]. With the establishment of the European Union, the relationship between cities and the countryside also seems to change, as the service sector, which plays a significant role within the national economy, operates in an urban environment. The centralization tendencies that are inherent in the functioning of the single market further strengthen cities, while the partial successes of the transformation of agriculture and depopulation clearly weaken rural areas [61]. Although interest in rural areas and their achievements and problems has increased in recent years, the scope of research still does not reach the depth of analyses conducted in the case of urban areas [62].

All over the world, the health condition of people living in rural areas is usually worse than those in urban areas. Several researches tried to analyse the cause of this tendency. The prior research showed that the number of medical staff living in the countryside is lower than in the urban areas per capita even in such developed countries as the United States of America [63] and this data shows it is more difficult for people living in the countryside to get involved in medical services of a quality available in the urban areas. The health status of the rural people is often compared with the health status of the urban people - and of course the available healthcare services are compared as well. Based on this comparison the health prospect of rural population is weaker than the health prospect of the urban population in Australia as well [64]. The health chances of the rural old people and mainly the chances of the left behind old people in the countryside cannot reach the level of the urban old people in China [65]. Basic health care is hardly provided in Hungarian urban areas as well where an increasing number of medical doctors and dentists working in the basic health care are missing [66]. Population and environmental health problems are critical factors in the relationship between poverty and health. It also encourages people to move from rural areas to the city [67].

However, it must not be forgotten that more than one billion people in major cities around the world live without proper waste management or drainage and breathe polluted air. City life is accompanied by a more stressful lifestyle leading to various cardiovascular diseases. Accordingly, it can be stated that both urban and rural areas have their disadvantages [68]. Interestingly, in the case of large cities, a process has begun that will result in people moving from increasingly expensive and less liveable cities to rural areas.

There are basically two social groups that typically move to small settlements in the catchment areas of large cities: wealthy people, desiring a more liveable, natural environment, and people falling behind and escaping from urban poverty. Obviously, the members of the two groups do not move to the same settlements, which may create significant differences between the settlements of suburban areas. Rich people move to settlements with good opportunities, which provide a healthy environment and easy access, while people with less favourable financial situation move to settlements with fewer opportunities that are less healthy and more difficult to access. This process further escalates the disadvantage of falling behind groups [69]. Due to poverty, poor health and the high burden of diseases in rural areas, special attention should be paid to improving the health of people living in rural and remote areas, in particular, if urban migration is to be slowed down. In general, lifestyle-related diseases are more common in rural areas. The peaks and depths of the economic cycle have a greater impact on rural communities [70]. The abovementioned levels of consumption are also lower in rural areas of the United States of America in 2001-2002, where alcohol and tobacco consumption is higher and nutrition levels are also more fluctuating than in urban areas [29]. A survey among young people showed that university students who migrate from rural areas to urban areas primarily justified their moving strategy with the higher number of available job opportunities in cities. However, immediately after job opportunities, lifestyle and living condition categories were the most important reasons, which is consistent with the results described above. Thus, young graduates of a university operating in the countryside of Hungary in 2017 are attracted by the benefits of urban living, including all the living conditions that have been listed above [71].

However, it can be seen that rural settlements strongly strive to create a positive image of themselves. Currently known as a major research area, the purpose of settlement marketing is to make the client settlements, including a large number of rural settlements, more attractive for potential investors and potential residents. With the appearance of investors, the general situation of these settlements improves, and as a result, they are able to catch up with more developed areas and improve all the properties that appear as potential sources of danger or cause of backwardness [72, 73]. The development of these settlements mostly depend on the amount of money spent on the different investments. To make a settlement more attractive for investors public expenditures needed to be completed in order to satisfy - for example - the infrastructural needs of the investors. In this case the public expenditures could be covered by local fiscal resources mostly based on the local taxation system, or by the support of the national budget (the source of the budgetary support can be international support provided for the country like the support of the European Union in many Member States that joined the EU in or after 2004). On the other hand, private investments can also support the development of the different settlements. In these cases, the investors will be able to realise extra profit upon their investments. The development of the settlements usually causes the rise of the salaries earned locally and because of 
this circumstance the average living standard and the average household income level can become higher as well causing willingness to consume more services and products offered partly by local companies [74].

Despite significant disparities between developing and developed countries, health and "access" to health is of key importance worldwide. Even in countries where the majority of the population lives in rural areas, resources are concentrated in cities. All countries experience difficulties related to transport and communication and all face a shortage of doctors and other health professionals in rural and remote areas [75]. The provision of medical services in rural and remote areas is significantly influenced by limited funding and other resource limits. As mentioned above, developing countries have significant poverty, limited opportunities and resources are available for health care. In many developed countries, funding for health services and infrastructural support for rural and remote communities has declined [76].

By means of its specific objectives, the WHO International Development Programme has developed a policy and action plan to promote sustainable subsistence, including access to land, resources and markets for people, and better education, health and opportunities for rural populations. It contributes to reducing child and maternal mortality and improving basic health care for all, including reproductive services. Training of the rural population, and in particular training along career paths available in the countryside is important in terms of addressing the challenges of rural areas. As a result of up-to-date knowledge, the labour market position of individuals improves and the improvement of rural areas is also easier [77].

The WHO has recently launched the "Towards the Unity for Health" project (TUHF). The objective of the project is to study and promote worldwide efforts to achieve unity of health service organizations, in particular through the sustainable integration of medicine and public health, or in other words, to consider individual health and community health activities and the impact on important reforms [78].

\subsection{The role of the countryside in the health promotion}

First of all, we have to clarify what countryside means. To be honest there is no single valid definition of countryside. Some of the researchers thought everything is countryside that is not an urban area [79], where people can still find space and fresh air [80]. Others are focussing on the development possibilities of the different areas saying every area is a countryside which is located in a periphery place with less inhabitants and with the potential and possibilities for development [81]. Many international organisations and researchers tried to find an inhabitant per unit area share which can separate urban and rural areas saying the highly populated areas are urban areas and everything else is the countryside [82, 83]. The Council of Europe declared that the countryside is a place where agriculture, forestry and fishery, the special economic and cultural activities of the rural people, recreation, and nature conservation are playing the dominant role in the everyday life [84]. As it could be seen from the abovementioned definitions there is no single definition of the countryside but after integration of several research aspects and analysing them with an interdisciplinary approach we would know what the notion 'countryside' means [85]. Based on the listed definitions we are describing rural areas under the name of the countryside where the population density is not that high and the inhabitants still have direct contact with nature. The countryside, the rural areas are representing a much higher share of the total land than the urban areas do.

On the other hand, the goals of sustainability and sustainable development could be reached in the countryside much easier than in urban areas. In cities and suburban areas many diseases are caused by low air quality, pollution. During urban planning specialists have to pay attention to these circumstances [86]. But, unfortunately, some public services are difficult to be gained in the countryside. However, recreational functions are mostly available in the countryside - for example rural areas could be easily used for recreation including outdoor sport activities - for all the people [87] lack of other services could be detected. As the population living in the countryside is changing the services offered by the local authorities are also changing. For example, as the population living in the countryside of England in 2010 is ageing the primary schools are getting closed and other services are also sold off [88].

Contacting the nature causes many benefits for people including health benefits as well. While the urban population has to seek for pieces of nature in their neighbourhood the rural population live their own life in a much more direct contact with nature, the environment [89]. Although, nowadays the urban population is continuously growing only the last few generations of humankind used to have the possibility to live in urban areas. For several thousand years, humankind had a much more direct contact with nature: facing challenges caused by the environment was a part of everyday life, sometimes with tragic outcomes [90]. Because of the rapid change of the lifestyle habits during the last generations' lifetime several new health problems occurred. This circumstance pushed the specialists and the decision makers to renew the traditional health services [91].

While the healthcare service system has to find the solution for the new problems people have to pay more attention to their vital and psychological health and wellbeing. As a part of this procedure people have to return to those physical activities which used to be a part of our ancestors' life and which kept them in good health condition. No one should be against the modern medicines and medical therapies but applying the practices our ancestors used to complete can make health promotion easier [92].

Contacting the nature helps not only in the health promotion but the psychological well-being as well and in these cases not only wildlands play important role but every small green part of cities including parks and backlot gardens as well [93]. The landscape and specially the landscape in the countryside can help health promotion in several ways. 
These health promotion methods could be divided into three categories. The landscape can serve the mental well-being with attention restoration, with the induction of positive thoughts and emotions and it is also able to reduce the stress level of the people. The landscape serves the needs of physical health promotion with the popularization of the everyday physical activities, with different walkable environments and by being a perfect place for leisure activities. And last but not least, the landscape can help the induction of social well-being when it promotes social integration, when it gives social support and security and when it strengthens social engagement and participation [94].

Unfortunately, in the last decades the popularity of the countryside shrinked, and this tendency was much stronger in developed countries. In the notion of 'countryside' many negative elements got mixed with the positive ones. The above listed positive characteristics are often combined with negative markers such as poverty, lagging, the disadvantages of the rural life [95]. But the overall social processes are not this simple. The flow of the population, the domestic migration mainly depends on the quality of the living place and on the possibilities available locally. That means any kind of settlement can become popular and can be a desired place to live if it is able to give vision for people and if it is able to serve the population's needs [96]. Employment possibilities, the available services and the local vision are making towns and villages attractive for the local population and for people coming from other settlements as well [71] because the directions of the population flow mostly depend on the available possibilities - including employment possibilities, leisure possibilities, basic services of healthcare, education and other social services -, on the geographical accessibility, and on the local policies formed by the population of the settlement.

Sporting events and possibilities as services can also serve the persistency of the young population in villages or towns because these kinds of services attract the university students as well [97]. When those rural citizens who temporarily used to move to bigger cities decide to move back to the countryside, they heft several circumstances. One of the most important factors affecting the return of citizens to the countryside is the availability of the sports infrastructure and the functioning of the local sports associations, sport clubs as it was reported in Hungary. The availability of this infrastructure and these services depends on the support of the government and of the local authorities [98]. The sport clubs are mostly civil associations operating in a non-profit framework but in the case of professional sport the presence of for-profit companies is getting more and more important both in Hungary and Germany as well [99]. The rate of public expenditures spent on different aims related to sport is higher than the local GDP growth in several parts of the world including Brazil, the United States of America, France, the United Kingdom, and China [100]. These factors all show that several governments realised that expenditures spent on sports can serve the health preservation of the citizens and can have such positive effects as it was listed above.
The sport as a direct influencer of health promotion is strongly linked to local communities and rural citizens paying attention to their physical and mental healthiness.

To strengthen the positive image of the countryside we have to support rural communities. The presence of employment possibilities and the positive generic approaches can revitalise the countryside. If the rural people can feel they can achieve as much as possible the countryside will become attractive again [101]. In the case of the development of rural areas it is crucial for local leaders to have clear targets they would like to reach. They need to have a vision they can share with the local communities [102].

In the countryside many services are provided by the local civilians. Their possibilities to offer services for the local people in many fields mostly depends on their fundraising possibilities. If they can get more income they can offer more services for local people. Because of this circumstance the support of the rural civilians and associations is crucial [103]. The quality and the availability of different services in the countryside mostly depend on the economic level of the investigated area. In regions suffering from poverty much less services are offered for the local population than in areas with higher economic performance [104].

\section{CONCLUSIONS}

The Earth and the whole humanity are facing many challenges nowadays and this trend will continue in the future as well. The overpopulation of the planet and the changing dietary habits are putting a great pressure on the agriculture and on the countryside as well. Researches focussing on the countryside mostly try to analyse different functions of the rural areas.

Nowadays the countryside has to serve different needs caused by the humanity. First of all, rural areas are the main places where agricultural activities are done and where people are producing and processing food. Although the food is mainly produced in the countryside the centres of consumption are located in urban areas. Secondly, the rural areas are functioning as homes of millions of people in Europe, billions of people worldwide. These people have needs they would like to get appeased near their homes. The services offered in the countryside depend on many factors like the economic status of the rural area, the population of the area, the location of the area, etc. Different rural areas are facing different challenges but there is a challenge which occurs globally: the population decrease of the countryside. People are migrating from the countryside to urban areas in order to find new possibilities and easier ways of making money. As it is shown in the article the availability of local services has a great effect on migration trends.

The countryside has a great role in health promotion as well. Based on different former researches we can state that people prefer to do physical activities in open air which is 
available in the countryside. One of the great advantages of the countryside is the direct connection with nature. But on the other hand, many differences could be found between the living standards of urban and rural areas. If decision makers would like to make the countryside more attractive they have to increase the available services there.

\section{ACKNOWLEDGEMENT}

The work/publication is supported by the Debrecen Venture Catapult Program, EFOP-3.6.1-16-2016-00022 project. The project is co-financed by the European Union and the European Social Fund.

\section{REFERENCES}

[1] C. E. Sachs, Gendered Fields. Rural Women, Agriculture, and Environment, New York, Routledge, 1996.

[2] C. Garriga, A. Hedlund, Y. Tang, and P. Wang, Rural-urban Migration, Structural Transformation, and Housing Markets in China. NBER Working Paper No. 23819, 2017, p. 49.

[3] P. M. Kőmíves, Gy. N. Szabados, G. Kulcsár, É. Bácsné Bába, V. Fenyves, and K. Dajnoki, “Visszatérni vidékre' A sport megtartó ereje," Int. J. Eng. Manag. Sci., vol. 3, no. 4, pp. 292-307, 2018.

[4] T. Glauben, H. Tietje, and C. Weiss, "Agriculture on the move: Exploring regional differences in farm exit rates in Western Germany," Jahrb. Regionalwiss., vol. 26, no. 1, pp. 103-18, 2006.

[5] C. Bain, T. Selfa, T. Dandachi, and S. Velardi, "'Superweeds' or 'survivors'? Framing the problem of glyphosate resistant weeds and genetically engineered crops," J. Rural Stud., vol. 51, pp. 211-21, 2017.

[6] S. B. Hecht, "The evolution of agroecological thought," in Agroecology. The Science of Sustainable Agriculture, M. A. Altieri, Ed., 2nd ed. Boca Raton, CRC Press Taylor \& Francis Group, 2018, pp. 1-20.

[7] M. S. DeLonge, A. Miles, and L. Carlisle, "Investing in the transition to sustainable agriculture," Environ. Sci. Policy, vol. 55, pp. 266-73, 2016.

[8] E. S. Deevey, “The human population," Sci. Am., vol. 203, pp. 194-204, 1960.

[9] C. Clark, Population Growth and Land Use, London, Macmillan, 1967.

[10] J. D. Durand, "Historical estimates of world population: An evaluation," Popul. Dev. Rev., vol. III, pp. 253-96, 1974.

[11] C. McEvedy and R. Jones, Atlas of World Population History, New York, Facts on File, 1978, pp. 342-51.

[12] W. M. Denevan, "The pristine myth: The landscape of the Americas in 1492," Ann. Assoc. Am. Geogr., vol. 82, no. 3, pp. 369-85, 1992.

[13] M. Kremer, "Population growth and technological change: One million B.C. to 1990," Q. J. Econ., vol. 108, no. 3, pp. 681-716, August 1993.

[14] A. Maddison, The World Economy: A Millennial Perspective, Paris, Development Centre of the Organization for Economic
Cooperation and Development, OECD, 2001, p. 384, ISBN 92-64-18998-X.

[15] Livi-Bacci, A Concise History of World Population. Oxford: Blackwell Publishing, 2007.

[16] H. Carl, How Many People Have Ever Lived on Earth? Population Reference Bureau, 2011.

[17] OECD, Investment Priorities for Rural Development, Paris, OECD Publishing, 2006.

[18] OECD, Rural-Urban Partnerships: An Integrated Approach to Economic Development, Paris, OECD Publishing, 2013. https:// doi.org/10.1787/9789264204812-en.

[19] OECD, Regions and Cities at a Glance 2018, Paris, OECD Publishing, 2018.

[20] United Nations, World Population Prospects, 2017. https://www. un.org/development/desa/publications/world-populationprospects-the-2017-revision.html.

[21] Worldometers, Current World Population, 2019. https://www. worldometers.info/world-population/.

[22] Ourworldindata.org, World Population Over the Last 12,000 Years and UN Projection Until 2100, 2017. https://ourworldindata.org/ grapher/world-population-1750-2015-and-un-projection-until2100 ? country=Our\%20World\%20In\%20Data-0+UN\%20Medium \%20Variant\%20Projection\%20(2019\%20revision)-0+OWID_ WRL-1.

[23] FAO, The Future of Food and Agriculture - Trends and Challenges, Rome, Food and Agriculture Organization of the United Nations, 2017, p. 180.

[24] C. B. d'Amour, F. Reitsma, G. Baiocchi, et al., "Future urban land expansion and implications for global croplands," Proc. Natl. Acad. Sci., vol. 114, pp. 8939-44, 2017.

[25] J. Popp, Z. Lakner, M. Harangi-Rákos, and M. Fári, “The effect of bioenergy expansion: Food, energy, and environment," Renew. Sustain. Energy Rev., vol. 32, pp. 559-78, 2014.

[26] T. Wheeler and J. Von Braun, "Climate change impacts on global food security," Science, vol. 341, pp. 508-13, 2013.

[27] W. E. Blum, "Functions of soil for society and the environment," Rev. Environ. Sci. Biotechnol., vol. 4, pp. 75-9, 2005.

[28] D. Fróna, "Globális kihívások a mezőgazdaságban," Int. J. Eng. Manag. Sci., vol. 3, no. 3, pp. 195-205, 2018.

[29] T. F. Borders and B. M. Booth, "Rural, suburban, and urban variations in alcohol consumption in the United States: Findings from the National Epidemiologic Survey on Alcohol and Related Conditions," J. Rural Health, vol. 23, no. 4, pp. 314-21, 2007.

[30] WORLDHUNGER, 2019, https://www.worldhunger.org/worldhunger-and-poverty-facts-and-statistics/.

[31] EASAC, Opportunities and Challenges for Research on Food and Nutrition Security and Agriculture in Europe. EASAC Policy Report 34, Halle, German National Academy of Sciences Leopoldina, 2017, p. 80.

[32] J. Szenderák, "Correlation clustering: Analysis of major agricultural commodity markets," Int. J. Eng. Manag. Sci., vol. 3, no. 3, pp. 288-302, 2018.

[33] S. Owens and R. Cowell, Lands and Limits. Interpreting Sustainability in the Planning Process, 2nd ed. London, Routledge, 2011.

[34] R. Boarini, A. Kolev, and A. McGregor, Measuring Well-being and Progress in Countries at Different Stages of Development: 
Towards a More Universal Conceptual Framework, OECD Development Centre Working Papers, 325, 2014, pp. 1-59.

[35] J. Vanhulst and A. E. Beling, "Buen vivir: Emergent discourse within or beyond sustainable development?," Ecol. Econ., vol. 101, pp. 54-63, 2014.

[36] N. Harris, "Exceptional spaces for sustainable living: The regulation of one planet developments in the open countryside," Plann. Theor. Pract., vol. 20, no. 1, pp. 11-36, 2019.

[37] A. E. Beling, J. Vanhulst, F. Demaria, V. Rabi, A. E. Carballo, and J. Pelenc, "Discursive synergies for g 'Great Transformation' towards sustainability: Pragmatic contributions to a necessary dialogue between human development, degrowth, and Buen Vivir," Ecol. Econ., vol. 144, pp. 304-13, 2018.

[38] EUROSTAT, Sustainable Developmnet in the European Union. Monitoring report on progress towards the SDGs in an EU context, Luxembourg, Publications Office of the European Union, 2019.

[39] E. Holden, K. Linnerud, and D. Banister, "Sustainable development: our common future revisted," Global Environ. Change, vol. 26, pp. 130-9, 2014.

[40] C. Labuschagne, A. C. Brent, and R. P. G. Van Erck, "Assessing the sustainability performances of industries," J. Clean. Prod., vol. 13, no. 4, pp. 373-85, 2005.

[41] J. P. Reganold, R. I. Papendick, and J. F. Parr, "Sustainable agriculture," Sci. Am., vol. 262, pp. 112-20, 1990.

[42] E. Öhlund, K. Zurek, and M. Hammer, "Towards sustainable agriculture? The EU framework and local adaptation in Sweden and Poland," Environ. Policy Govern., vol. 25, pp. 270-87, 2015.

[43] M. Antal, "Green goals and full employment: are they compatible?” Ecol. Econ., vol. 107, pp. 276-86, 2014.

[44] M. Chaves, T. Macintyre, G. Verschoor, and A. E. J. Wals, "Radical ruralities in practice: Negotiating buen vivir in a Colombian network of sustainability," J. Rural Stud., vol. 59, pp. 153-62, 2018.

[45] J. Guardiola and F. García-Quero, "Buen Vivir (living well) in Ecuador: Community and environmental satisfaction without household material prosperity?" Ecol. Econ., vol. 107, pp. 177-84, 2014.

[46] T. Pinto-Correira, C. Gonzalez, L. A. Sutherland, and M. Peneva, "Lifestyle farming: countryside consumption and transition towards new farming models," in Transition Pathways Towards Sustainability in Agriculture: Case Studies from Europe, L. Sutherland, I. Darnhofer, G. A. Wilson, and L. Zagata, Eds., Wallingford, CABI, 2015, pp. 67-81.

[47] J. F. L. Sørensen, "The importance of place-based, internal resources for the population development in the small rural communities," J. Rural Stud., vol. 59, pp. 78-87, 2018.

[48] S. R. Gliessman, Agroecology: The Ecology of Sustainable Food Systems, 3rd ed. Boca Raton, CRC Taylor \& Francis Group, 2014.

[49] S. Gliessman, "Transforming food systems with agroecology," Agroecol. Sustain. Food Syst., vol. 40, no. 3, pp. 187-9, 2016.

[50] EUROSTAT, Statistics on Rural Areas in the EU, 2018. https://ec. europa.eu/eurostat/statistics-explained/index.php/Statistics_on_ rural_areas_in_the_EU.

[51] United Nations, World Urbanization Prospects: The 2011 Revision, New York, UN Department of Economic and Social Affairs, Population Division, 2012.
[52] EUROSTAT, Urban-Rural Typology, 2014, https://ec.europa.eu/ eurostat/statistics-explained/index.php/Archive:Urban-rural_ typology.

[53] B. Biagi, M. G. Ladu, and M. Meleddu, "Urban quality of life and capabilities: An experimental study," Ecol. Econ., vol. 150, pp. 137-52, 2018. https://doi.org/10.1016/j.ecolecon.2018.04.011.

[54] J. Romão, K. Kourtit, B. Neuts, and P. Nijkamp, "The smart city as a common place for tourists and residents: A structural analysis of the determinants of urban attractiveness," Cities, vol. 78, pp. 67-75, 2018.

[55] G. Waitt and C. Gibson, "Creative small cities: Rethinking the creative economy in place," Urban. Stud., vol. 46, no. 5-6, pp. 1223-46, 2009.

[56] R. M. Vanderbeck and C. Morse Dunkley, "Young people's narratives of rural-urban difference," Child. Geogr., vol. 1, no. 2, pp. 241-59, 2003.

[57] C. Fertner, N. B. Groth, L. Herslund, and T. A. Carstenses, "Small towns resisting urban decay through residential attractiveness. Findings from Denmark," Geografisk Tidsskrift - Dan. J. Geogr., vol. 115, no. 2, pp. 119-32, 2015.

[58] R. Horeczki, “A dél-dunántúli kisvárosok a fejlesztési tervek tükrében," DETUROPE - Cent. Eur. J. Reg. Dev. Tourism, vol. 6, no. 3, pp. 97-111, 2014.

[59] M. Harangi-Rákos and G. Szabó, "The economic and social role of private farm sin Hungarian agriculture," Appl. Stud. Agribus. Commer. - APSTRACT, vol. 6, no. 5, pp. 33-41, 2012.

[60] A. Broadbridge and E. Calderwood, "Rural grocery shoppers: do their attitudes reflect their actions?," Int. J. Retail Distrib. Manag., vol. 30, no. 8, pp. 394-406, 2002.

[61] M. Memagh and P. Commins, Europe 2000: Meeting the Challenge of Exclusion in Peripheral Rural Areas, Dublin, Poverty 3 RDU, 1992.

[62] B. Jentsch and M. Shucksmith, "Introduction," in Young People in Rural Areas of Europe, B. Jentsch and M. Shucksmith, Eds., London, Routledge, 2004.

[63] J. N. Bolin, G. R. Bellamy, A. O. Ferdinand, et al., "Rural healthy people 2020: New decade, same challenges," J. Rural Health, vol. 31, pp. 326-33, 2015.

[64] C. Malatzky and L. Bourke, "Re-producing rural health: Challenging dominant discourses and the manifestation of power," $J$. Rural Stud., vol. 45, pp. 157-64, 2016.

[65] Y. Zhong, P. Schön, B. Burström, and K. Burström, "Association between social capital and health-related quality of life among left behind and not left behind older people in rural China," BMC. Geriatr., vol. 17, 2017, Article no. 287.

[66] G. Nagy, "Ellátás és ellátatlanság - Köz- és piaci szolgáltatások területi-települési egyenletlenségei a vidéki Magyarországon," Földrajzi Közlemények, vol. 143, no. 2, pp. 124-43, 2019.

[67] J. Humphreys, D. Hegney, J. Lipscombe, G. Gregory, and B. Chater, "Whither rural health? Reviewing a decade of progress in rural health," Aust. J. Rural. Health., vol. 10, pp. 2-14, 2002.

[68] K. B. Smith, J. S. Humphreys, and M. G. A. Wilson, "Addressing the health disadvantage of rural populations: How does epidemiological evidence inform rural health policies and research?," Aust. J. Rural. Health., vol. 16, pp. 56-66, 2008.

[69] G. Vasárus, "Külterületi szuburbanizáció és szegregáció," Településföldrajzi Tanulmányok, vol. 1, pp. 84-94, 2016. 
[70] D. Hartley, "Rural health disparities, population health and rural culture," Am. J. Public. Health, vol. 94, no. 10, pp. 1675-8, 2004.

[71] K. Dajnoki, Gy. N. Szabados, G. Kulcsár, P. M. Kőmíves, and É. Bácsné Bába, “Visszatérni vidékre' - Hallgatói vidékképek kvalitatív megközelítésben,” Int. J. Eng. Manag. Sci., vol. 3, no. 5, pp. 204-16, 2018.

[72] I. Tózsa, “A településmarketing elmélete," in Turizmus és településmarketing, I. Tózsa, Ed., Budapest, Budapesti Corvinus Egyetem Gazdaságföldrajz és Jövőkutatás Tanszék, 2014, pp. 129-58.

[73] J. Rechnitzer, "Vázlatpontok a településmarketing értelmezéséhez és kidolgozásához," Tér és Társadalom, vol. 9, no. 1-2, pp. 5-16, 1995.

[74] J. Káposzta, “A jó kormányzás regionális összefüggései a vidéki térben," Stud. Mundi - Econ., vol. 5, no. 3, pp. 70-8, 2018.

[75] Strasser R, "Rural health around the world: Challenges and solutions," Fam. Pract., vol. 20, no.4, pp. 457-63, August 2003, https://doi.org/10.1093/fampra/cmg422.

[76] J. Bernard, "Where have all the rural poor gone? Explaining the rural-urban poverty gap in European countries," Sociol. Rural., vol. 59, no.3, 2019, https://doi.org/10.1111/soru.12235.

[77] P. M. Kőmíves, P. Pilishegyi, N. Novák, A. Sz. Nagy, and P. Körösparti, "The role of the higher education in the development of the agriculture," Int. J. Inf. Educ. Technol., vol. 9, no. 9, pp. 607-12, 2019.

[78] C. Boelen, Towards Unity for Health. Challenges and Opportunities for Partnership in Health Development. A working paper. World Health Organization, Geneva, 2000.

[79] T. Quendler, Entwicklungsprogram für die Land- und Forstwirtschaft, Steiermark, LR-Aktuell, 1986, pp. 3-14.

[80] B. Boros, "Keljfeljancsi: a feje tetejére állított világ," A Falu, vol. 2, pp. 15-21, 2001.

[81] H. K. Wytrzens, Agrarplanung, Wien, Köln. Weimar, Böhlau Verlag, 1994.

[82] A. Fehér and L. Dorgai, A vidék eltartó-képességének stabilizálása, regionális összefüggései, Budapest, MTA Agrártudományok Osztálya, 1998, pp. 7-43.

[83] T. Dax, "Defining rural areas: International comparisons and the OECD indicators," Rural Soc., vol. 3, pp. 3-18, 1996.

[84] Council of Europe, European Rural Heritage Observation Guide, Strasbourg, CEMET. Council of Europe, 2003.

[85] A. D. Kovács, J. Zs. Farkas, and É. Perger, "A vidék fogalma, lehatárolása és új tipológiai kísérlete," Tér és Társadalom, vol. 29, no. 1, pp. 11-34, 2015.

[86] W. Zhou, S. T. A. Pickett, and M. L. Cadenasso, "Shifting concepts of urban spatial heterogeneity and their implications for sustainability," Landsc. Ecol., vol. 32, no. 1, pp. 15-30, 2017.

[87] K. Hornigold, I. Lake, and P. Dolman, "Recreational use of the countryside: No evidence that high nature value enhances a key ecosystem service," PLoS One, vol. 11, no. 11, pp. 1-14, 2016.

[88] I. Cabras and C. K. Lau, "The availability of local services and its impact on community cohesion in rural areas: Evidence from the
English countryside," Local Econ. J. Local Econ. Policy Unit, vol. 34, no. 3, pp. 248-70, 2019.

[89] C. Maller, M. Townsend, A. Pryor, P. Brown, and L.St. Leger, "Healthy nature healthy people: 'Contact with nature' as an upstream health promotion intervention for populations," Health. Promot. Internation., vol. 21, no. 1, pp. 45-54, 2005.

[90] D. Suzuki, The Sacred Balance: Rediscovering Our Place in Nature, St Leonards, Allen and Unwin, 1997.

[91] G. S. Guldan, "Obstacles to community health promotion," Soc. Sci. Med., vol. 43, no. 5, pp. 689-95, 1996.

[92] S. B. Eaton, L. Cordain, and S. Lindeberg, "Evolutionary health promotion: A consideration of common counterarguments," Prev. Med., vol. 34, no. 2, pp. 119-23, 2002.

[93] J. Pretty, J. Peacock, R. Hine, M. Sellens, N. South, and M. Griffin, "Green exercise in the UK countryside: Effects on health and psychological well-being, and implications for policy and planning," J. Environ. Plann. Manag., vol. 50, no. 2, pp. 211-31, 2007.

[94] A. Abraham, K. Sommerhalder, and T. Abel, "Landscape and well-being: a scoping study on the health-promoting impact of outdoor environments," Int. J. Public Health, vol. 55, no. 1, pp. 59-69, 2010.

[95] B. Short, "Idyllic ruralities," in P. Cloke, T. Marsden, P. Mooney, Eds., Handbook of Rural Studies. London, SAGE Publicatios, 2006, pp. 133-48.

[96] T. Valuch, Magyarország társadalomtörténete a XX. század második felében, Budapest, Osiris Kiadó, 2005.

[97] C. Pfau and Sz. Domonkos, "Szabadidősport a felsőoktatásban," Taylor Gazdálkodás- és Szervezéstudományi Folyóirat, vol. 8, no. 2, pp. 111-7, 2016.

[98] A. Becsky, I. Dékán Tamásné Orbán, Z. Bács, and A. Herczeg, "Financing and operating questions of sports facilities," Appl. Stud. Agribus. Commer. - APSTRACT, vol. 9, no. 1-2, pp. 5-8, 2015.

[99] É. Bácsné Bába, "Szervezeti megoldások sikeres sportvállalkozások esetében - a német példa," Taylor, vol. 7, no. 3-4, pp. 286-94, 2015.

[100] É. Bácsné Bába, R. Balogh, Z. Bács, V. Fenyves, and K. Dajnoki, "Sportszolgáltatások keresleti, kínálati oldalának elemzési lehetőségei," Stud. Mundi - Econ., vol. 5, no. 3, pp. 19-33, 2018.

[101] J. Wainer and J. Chesters, "Rural mental health: neither romanticism nor despair," Aust. J. Rural. Health, vol. 8, no. 3, pp. $141-7,2000$.

[102] T. Tóth, "Gazdaságfejlesztési lehetőségek a jól múködő településeken,” Stud. Mundi - Econ., vol. 5, no. 1, pp. 59-67, 2018.

[103] Gy. N. Szabados and G. Kulcsár, "Vidéki civilek - vidéki forrásteremtési lehetőségek," Taylor Gazdálkodás- és Szervezéstudományi Folyóirat, vol. 9, no. 2, pp. 23-30, 2017.

[104] D. W. Brinkerhoff, A. Wetterberg, and E. Wibbels, "Distance, services, and citizen perceptions of the state in rural Africa," Governance, vol. 31, no. 1, pp. 103-24, 2018. 